\title{
PHILIP CORDER, M.A., LitT.D.
}

\author{
Assistant Secretary, r $943-196$ I
}

THE death of Dr. Corder on 29 May I96I was a sudden shock to the Society and to the many friends outside it who held our Assistant Secretary in high esteem. While resting during a motor-journey, he received a stroke from which he had hardly recovered before further attacks supervened, and he died at Northampton. There he now lies, in a quiet corner of the Burial Ground of the Society of Friends.

The end was much what he would have wished. Vivid, keen, an ardent partaker in all activities that he loved, he hated the thought either of retirement or of a lingering illness. Few guessed that he was seventy years of age, for his physique, his manner, and his sympathies were those of a considerably younger man: and it was this fundamental vitality and ready resilience of wit and mind that made him personally so beloved within our Society. He served it well, having come to it with a wealth of experience. His first important post had been as a master at Bootham School, York, where he taught English with long-remembered insight and enthusiasm. Then, at a time of life when many natures yearn for a new existence, he became curator of the Verulamium Museum, winning this appointment not only by his personality but in the light of the expertise which he had gained as an excavator of very various types of Romano-British sites in East Yorkshire. This was for him a joyous activity, for it offered the opportunity to demonstrate practically his belief in the educative value of antiquity when reinforced by the evocative power of actual objects. That faith illumined his numerous works and papers, and was the basis of his especial aptitude in adult education, so well proved both at St. Albans and later at Great Casterton, where for ten years he conducted a highly successful course in excavation. There was no one who by word and action could better convey the humane comity of scholarship; and a vivid trust in rational inquiry as a bond of unity between all sorts and conditions of men lay at the very root of his nature.

These qualities, ripened by a life-time's experience and warmed by the regard which he had for our Society, made him an Assistant Secretary who was no mere official, but who, like his predecessors in office, formed his own particular and inimitable pattern of service and relationships. He was greatly beloved by his staff and devoted to them, while the Fellowship found in him a careful and methodical administrator, an editor whose meticulosity was matched by learning and ingenuity and developed by his own extensive written output, and a friend of proved loyalty, wisdom and sensibility. The breadth of his knowledge and interests reflected itself in the widest possible enthusiasm for all that the Society did. Just as he could never be accused of over-zealous partisanship for the archaeological activities that were his own interest, so he would never acquiesce in the exaltation of one kind of work at the expense of another. This unfeigned impartiality and manifest integrity were the open secret of his popularity and of the deep regard in which he was held, and no epitaph will be needed upon a grave so richly strewn with kindly memories.

I. A. R. 